\title{
Pembinaan Disiplin Kerja Pegawai di PUPR Balai Wilayah Sungai Sumatera V SNVT Pelaksanaan Jaringan Pemanfaatan Air IAKR
}

\author{
Tania Zemerlin ${ }^{1}$, Irsyad ${ }^{2}$, Jasrial ${ }^{3}$, Yulianto Santoso ${ }^{4}$ \\ ${ }^{1}$ Administrasi Pendidikan, Universitas Negeri Padang $1,{ }^{2}$ Administrasi Pendidikan, Universitas Negeri Padang $2,{ }^{3}$ \\ Administrasi Pendidikan, Universitas Negeri Padang $3,{ }^{4}$ Administrasi Pendidikan, Universitas Negeri Padang 4 \\ Tania Zemerlin ${ }^{1}$, e-mail: taniazmrlin@gmail.com \\ Irsyad $^{2}$, e-mail: irsyad@ fip.unp.ac.id \\ Jasrial ${ }^{3}$, e-mail: jasrial36@gmail.com \\ Yulianto Santoso ${ }^{4}$, e-mail: yuliantosantoso@ fip.unp.ac.id
}

\begin{abstract}
This research was made to obtain information at PUPR Balai Sungai Sumatera V SNVT Implementation of IAKR Water Utilization Network regarding: 1) Leadership Assertiveness, 2) Leadership Model, 3) Supervision Activities, and 4) Sanctions for Violations. The author uses descriptive or quantitative research. The author used a questionnaire in this study with a Likert scale model with a population of all employees at PUPR Balai Sungai Sumatera V SNVT Implementation of the IAKR Water Utilization Network, amounting to 62 employees, the number of samples that researchers used for this study amounted to 38 people taken $10 \%$ of the population. The results of what the researchers found at PUPR Balai Sungai Sumatera V SNVT Implementation of IAKR Water Utilization Network are: 1) Assertiveness of leaders with an average number of 3.86 is in good criteria, 2) exemplary leadership with an average number of 4.00 are in good criteria, 3) Supervision activities with an average number of 3.78 are in good criteria, and 4) Sanctions for violations with an average number of 4.05 are in good criteria. Overall, it can be seen that the level of employee work discipline development at PUPR Balai Sungai Sumatera V SNVT Implementation of IAKR Water Utilization Network with an average number of 3.92 on good criteria.
\end{abstract}

\begin{abstract}
Abstrak
Penelitian ini dibuat untuk mendapatkan informasi di PUPR Balai Wilayah Sungai Sumatera V SNVT Pelaksanaan Jaringan Pemanfaatan Air IAKR mengenai: 1) Ketegasan Pimpinan, 2) Keteladanan Pimpinan, 3) Kegiatan Pengawasan, dan 4) Sanksi atas Pelanggaran. Penulis menggunakan penelitian deskriptif atau kuantitatif. Penulis menggunakan angket dalam penelitian ini dengan model skala likert dengan populasi seluruh pegawai di PUPR Balai Wilayah Sungai Sumatera V SNVT Pelaksanaan Jaringan Pemanfaatan Air IAKR yang berjumlah 62 pegawai, banyaknya sampel yang peneliti gunakan untuk penelitian ini berjumlah 38 orang yang diambil $10 \%$ dari populasi. Hasil dari yang peneliti temukan di PUPR Balai Wilayah Sungai Sumatera V SNVT Pelaksanaan Jaringan Pemanfaatan Air IAKR adalah: 1) Ketegasan pimpinan dengan jumlah rata-rata 3,86 berada pada kriteria yang baik, 2) Keteladanan pimpinan dengan jumlah rata-rata 4,00 berada pada kriteria yang baik, 3) Kegiatan Pengawasan dengan jumlah rata-rata 3,78 berada pada kriteria yang baik, dan 4) Sanksi atas pelanggaran dengan jumlah ratarata 4,05 berada pada kriteria yang baik. Secara keseluruhan dapat diketahui bahwa tingkat pembinaan disiplin kerja pegawai di PUPR Balai Wilayah Sungai Sumatera V SNVT Pelaksanaan Jaringan Pemanfaatan Air IAKR dengan jumlah rata-rata 3,92 pada kriteria yang baik.
\end{abstract}

Kata Kunci: Pembinaan Disiplin Kerja Pegawai

How to Cite: Zemerlin, Tania, Irsyad, Jasrial, Yulianto Santoso. 2021 "Pembinaan Disiplin Kerja Pegawai di PUPR Balai Wilayah Sungai Sumatera V SNVT Pelaksanaan Jaringan Pemanfaatan Air IAKR”. Human Resource Management, Vol

\section{Pendahuluan}


SDM punya peran penting untuk tercapainya tujuan, karena SDM lah yang membuat faktor-faktor lain bisa melakukan fungsinya. Kualitas dan kemampuan SDM inilah yang memiliki pengaruh besar terhadap kinerja organisasi.

Disiplin kerja adalah suatu fungsi manajemen SDM yang berperan penting untuk terwujudnya suatu tujuan, karena jika tidak ada disiplin suatu organisasi sulit untuk memenuhi tujuan secara maksimum . Pembinaan disiplin juga bisa mendorong para pegawai agar patuh terhadap tata peraturan yang berlaku di kantor yang bertujuan untuk mencegah terjadinya pelanggaran-pelanggaran terhadap peraturan yang ada di kantor dengan tujuan untuk membina disiplin diri pegawai. (Sedarmayanti, 2010:221). Disiplin kerja adalah usaha untuk menaikan kesesuaian pegawai untuk mengikuti semua tata tertib yang ada di kantor serta sesuai norma sosial berlaku.

Pegawai adalah orang yang mencukupi persyaratan yang telah ditetapkan dalam suatu susunan undangundang yang ada, diangkat oleh seorang pejabat yang berwewenang dan di beri tugas jabatan negara yang ditetapkan pada peraturan perundang-undangan dan diberi gaji menurut peraturan perundang-undang yang ada. Seorang pemimpin pun mempunyai peran yang sangat penting sebab peran seorang pemimpin sangat menentukan terhadap keberhasilan atau kegagalan dalam menyelesaikan misi institusi. Beberapa faktor yang menyebabkan belum optimalnya disiplin para pegawai di PUPR Balai Wilayah Sungai Sumatera V SNVT Pelaksanaan Jaringan Pemanfaatan Air IAKR adalah disiplin kerja.

Berdasarkan pengamatan yang penulis temui di PUPR Balai Wilayah Sungai Sumatera V SNVT Pelaksanaan Jaringan Pemanfaatan Air IAKR ada beberapa fenomena-fenomena sebagai berikut:

1. Masih ditemukan pegawai kurang mengetahui tentang tata tertib dan peraturan-peraturan yang berlaku.

2. Masih ditemukan pegawai terlambat datang ke kantor disebabkan ada beberapa orang pimpinan pada bagian kantor tersebut juga datang terlambat.

3. Pimpinan jarang meninjau secara langsung terhadap kegiatan yang sedang dilakukan oleh pegawai.

4. Pimpinan masih kurang tegas memberikan sanksi/hukuman kepada pegawai.

\section{Metode penelitian}

Penelitian berjenis deskriptif atau kuantitatif yaitu mengungkapkan data yang menggambarkan sebagaimana adanya. Sugiyono (2012:147) penelitian deskriptif yaitu "penelitian untuk menelaah data dengan cara menguraikan dan menggambarkan data yang dikumpulkan serta tidak bertujuan untuk menjadikan suatu kesimpulan menjadi populer". Jumlah populasi yang digunakan dalam penelitian ini adalah 62 orang yang merupakan seluruh pegawai di PUPR Balai Wilayah Sungai Sumatera V SNVT Pelaksanaan Jaringan Pemanfaatan Air IAKR. Sampel penelitian ini diambil memakai teknik Proportionate Stratified Random Sampling dengan besaran sampel 38 pegawai setelah terjadi pembulatan angka.

Instrumen yang dipakai pada pemungutan data pada penelitian ini yaitu angket model skala Likert. (Arikunto, 2010:129) Angket disusun dengan lima alternatif jawaban.

\section{Hasil dan pembahasan}

Hasil yang diberikan dalam penelitian ini menguraikan terkait pembinaan disiplin kerja pegawai di PUPR Balai Wilayah Sungai Sumatera V SNVT Pelaksanaan Jaringan Pemanfaatan Air IAKR dilihat dari aspek 1) Ketegasan pimpinan, 2) Keteladanan pimpinan, 3) Kegiatan Pengawasan dan 4) Sanksi atas pelanggaran yang dijelaskan dengan tabel berikut ini:

Tabel 9. Rekapitulasi Skor pada Rata-rata Pembinaan Disiplin Kerja Pegawai di PUPR Balai Wilayah Sungai Sumatera V SNVT Pelaksanaan Jaringan Pemanfaatan Air IAKR

\begin{tabular}{|c|l|c|c|}
\hline No. & \multicolumn{1}{|c|}{ Indikator } & Skor Rata-rata & Kategori \\
\hline 1 & Ketegasan Pimpinan & 3,86 & Baik \\
\hline 2 & Keteladanan Pimpinan & 4,00 & Baik \\
\hline 3 & Kegiatan Pengawasan & 3,78 & Baik \\
\hline 4 & Sanksi Atas Pelanggaran & 4,05 & Baik \\
\hline & Rata-rata & $\mathbf{3 , 9 2}$ & Baik \\
\hline
\end{tabular}


Secara keseluruhan menunjukkan bahwa hasil penelitian terkait pembinaan disiplin kerja pegawai di PUPR Balai Wilayah Sungai Sumatera V SNVT Pelaksanaan Jaringan Pemanfaatan Air IAKR dinyatakan baik dengan rata-rata 3,92.

\subsection{Pembahasan tentang pembinaan Disiplin Kerja Pegawai Dilihat dari Aspek Ketegasan Pimpinan}

Hasibuan (2202:18), Ketegasan seorang pemimpin dalam melakukan suatu tindakan sangat berpengaruh terhadap kedisiplinan pegawai di kantor. Pimpinan wajib bersikap berani serta tegas kepada pegawai, berperan untuk membina setiap tenaga kerja yang tidak disiplin sesuai dengan ganjaran yang telah berlaku. Ketegasan seorang pemimpin dalam menasihati dan menghukum setiap pegawai yang tidak disiplin dapat menjadikan kepatuhan yang baik di kantor.

Hasil yang peneliti dapatkan terkait pembinaan disiplin kerja pegawai dari aspek ketegasan pimpinan memperoleh jumlah rata-rata 3,86. Dengan skor rata-rata ini berada pada kategori yang baik. oleh sebab itu pimpinan harus mempertahankan agar meningkatnya ketegasannya terhadap pegawai untuk meningkatkan disiplin kerja pegawai menjadi sangat baik. penelitian ini menunjukkan bahwa skor tertinggi berada pada item, pimpinan dapat menggerakkan pegawai untuk mencapai tujuan kantor yang lebih baik dengan memperoleh jumlah rata-rata 4,32. Skor terendah Pimpinan memberi sanksi kepada pegawai yang suka melalaikan pekerjaan pada jumlah rata-rata 3,63.

Penyebab rendahnya rata-rata skor pada Pimpinan memberi sanksi kepada pegawai yang suka melalaikan pekerjaan adalah masih kurangnya pemberian sanksi yang dilakukan oleh pimpinan terhadap pegawainya sehingga masih ada ditemukan pegawai yang semena-mena dalam bekerja, oleh karena itu pimpinan dapat lebih tegas lagi terhadap pemberian sanksi kepada pegawai yang semenamenanya dalam bekerja untuk mencapai tujuan kantor yang lebih baik.

3.2. Pembahasan tentang Pembinaan Disiplin Kerja Pegawai Dilihat dari Aspek Keteladanan Pimpinan

Hadiyanto (2000:94), sumbangan yang sangat besar dari pihak organisasi atau lembaga untuk perkembangan pribadi seorang pegawai dan sosial pegawai yaitu apa yang telah pimpinan berikan. Pimpinan dapat memberikan contoh baik kepada pegawai, disiplin yang baik, jujur, adil, dan kata sebanding dengan tindakan. Jika pemimpin mempunyai sifat yang baik maka kedisiplinan akan baik.

Hasil yang penelitian dapatkan terkait pembinaan disiplin kerja pegawai dari aspek keteladanan pimpinan memperoleh jumlah rata-rata 4,00. Dengan skor rata-rata ini berada pada kategori yang baik. oleh sebab itu pimpinan dapat mempertahankan serta memajukan keteladanannya untuk meningkatkan teladan seorang pemimpin menjadi sangat baik. penelitian ini menunjukkan bahwa skor tertinggi berada pada item, pimpinan memakai pakaian yang rapi dan sopan selama bekerja di kantor. dengan memperoleh jumlah rata-rata 4,50. Skor terendah Pimpinan mengadakan dan menghadiri apel pagi setiap minggu dengan jumlah rata-rata 3,68.

Penyebab rendahnya rata-rata skor pada Pimpinan mengadakan dan menghadiri apel pagi setiap minggu adalah kurangnya kesadaran pimpinan terhadap kegiatan apel pagi yang dilakukan setiap minggunya, oleh karena itu pimpinan dapat lebih intropeksi diri dan mendisiplinkan diri untuk kemajuan kantor yang lebih baik.

\subsection{Pembahasan tentang Pembinaan Disiplin Kerja Pegawai Dilihat dari Aspek Kegiatan Pengawasan}

Hadari Nawawi (1990:60) mengemukakan bahwa "sasaran dari pengawasan melekat adalah pembinaan personel yang bertujuan agar personil dalam organisasi memiliki disiplin yang tinggi”. Dengan dilakukannya pengawasan melekat maka atasan dapat berperan aktif dan langsung mengawasi kerja pegawainya.

Hasil penelitian mengenai pembinaan disiplin kerja pegawai dari aspek kegiatan pengawasan dengan perolehan jumlah rata-rata 3,78. Skor dengan rata-rata ini berada di kategori baik. oleh karena itu pimpinan dapat mempertahankan serta meningkatkan pengawasannya terhadap pegawai di kantor atau di lapangan agar meningkatkan pengawasan yang dilakukan oleh pimpinan menjadi sangat baik. penelitian ini menunjukkan bahwa skor tertinggi berada pada item Pimpinan memantau ketepatan waktu pegawai dalam menyelesaikan tugas. dengan perolehan jumlah rata-rata 3,92. Skor terendah Pimpinan mengawasi disiplin pegawai dalam mengikuti apel pagi dengan perolehan jumlah rata-rata 3,47 .

Penyebab rendahnya rata-rata pada skor pimpinan mengawasi disiplin pegawai dalam mengikuti apel pagi adalah masih kurangnya kesadaran pimpinan terhadap kegiatan apel pagi yang dilakukan setiap minggunya, oleh karena itu pimpinan dapat lebih intropeksi diri dan mendisiplinkan diri agar pegawai ikut disiplin untuk hadir pada kegiatan apel pagi yang dilakukan setiap minggunya untuk kemajuan kantor yang lebih baik. 


\subsection{Pembahasan tentang Pembinaan Disiplin Kerja Pegawai Dilihat dari Aspek Sanksi atas Pelanggaran}

Veithzal Rivai (2011:831) mengemukakan bahwa "setiap ucapan yang disebut, tulisan, perbuatan seseorang yang melanggar aturan disiplin yang sudah diatur pada sebuah instansi. Sementara itu sanksi atas pelanggaran kerja yaitu balasan disiplin yang diberikan oleh pemimpin di sebuah instansi untuk pegawainya yang telah melanggar aturan-aturan disiplin yang sudah diterapkan pimpinan pada sebuah instansi”. Sanksi atas pelanggaran berperan penting untuk memelihara serta membina disiplin kerja pegawai. Dengan sanksi hukuman yang diberikan semakin berat kepada pegawai, maka pegawai akan semakin takut untuk melanggar peraturan yang ada di instansi, dan sikap tidak disiplin pegawai akan menurun.

Hasil penelitian terkait pembinaan disiplin kerja pegawai dari aspek sanksi atas pelanggaran memperoleh jumlah rata-rata 4,05. Skor dengan rata-rata ini berada di kategori baik. oleh karena itu pimpinan dapat mempertahankan serta meningkatkan pemberian sanksi atas pelanggaran yang dilakukan pegawai agar sanksi yang ada di kantor diterapkan dengan sangat baik. penelitian ini menunjukkan bahwa skor tertinggi berada pada item Pemberian sanksi pada pelanggaran disiplin diberikan secara bertingkat, mulai dari yang ringan. dengan perolehan jumlah rata-rata 4,24. Skor terendah pimpinan memberikan teguran kepada pegawai yang sering datang terlambat dengan perolehan jumlah rata-rata 3,89 .

Penyebab rendahnya rata-rata skor pada pimpinan memberikan teguran kepada pegawai yang sering datang terlambat ke kantor adalah masih kurangnya pimpinan melakukan teguran terhadap tenaga kerja yang melanggar aturan-aturan di kantor, karena itu pimpinan dapat lebih tegas menerapkan pemberian hukuman terhadap tenaga kerja yang suka melanggar peraturan, pemberian hukuman bisa dilakukan secara bertingkat dari yang ringan hingga yang berat, agar pegawai lebih mendisiplinkan diri di kantor dan dapat mencapai tujuan kantor yang lebih baik.

\section{Kesimpulan}

Dari hasil dan pembahasan di PUPR Balai Wilayah Sungai Sumatera V SNVT Pelaksanaan Jaringan Pemanfaatan Air IAKR dapat disimpulkan : Pembinaan disiplin kerja pegawai dilihat dari aspek ketegasan pimpinan cukup terlaksana baik dengan perolehan hasil 3,86. Pembinaan disiplin kerja pegawai dilihat dari aspek keteladanan pimpinan cukup terlaksana baik dengan perolehan hasil 4,00. Pembinaan disiplin kerja pegawai dilihat dari aspek kegiatan pengawasan cukup terlaksana baik dengan perolehan hasil 3,78. Pembinaan disiplin kerja pegawai dilihat dari aspek sanksi atas pelanggaran cukup terlaksana baik dengan perolehan hasil 4,05. Pembinaan disiplin kerja pegawai secara keseluruhan cukup terlaksana baik dengan perolehan hasil 3,92.

\section{DAFTAR RUJUKAN}

Arikunto Suharsimi. (2010). Prosedur Penelitian suatu Pendekatan Praktis. Jakarta: Rineka Cipta.

Hadiyanto. (2000). Manajemen Peserta Didik. Padang: UNP.

Kepemimpinan, P. G., Kerja, D. A. N. D., Tewal, B., Dotulong, L., Ekonomi, F., \& manajemen, J. (2018).

Pengaruh Gaya Kepemimpinan, Pengawasan, dan Disiplin Kerja Terhadap Kinerja Pegawai Pada Dinas

Perhubungan Kabupaten Minahasa Tenggara. Jurnal EMBA: Jurnal Riset Ekonomi, Mabajemen, Bisnis

Dan Akuntansi. https://doi.org/10.35794/emba.v6i4.20919

Melayu, H. (2002). Manajemen Sumber Daya Manusia. Jakarta: Bumi Aksara.

Nawawi, H. (1995). Pengawasan Melekat di Lingkungan Aparatur Pemerintaha. Pontianak: Erlangga.

Sedarmayanti. (2010). Manajemen Sumber Daya Manusia. Refika Aditama, Bandung.

Sugiyono. (2012). Metode Penelitian Administrasi. Bandung: Alfabeta. 2007.

Veithzal, R. (2011). manajemen sumber daya manusia untuk perusahaan. Jakarata: Rajawali Pers. 